\title{
REGISTRATION UNDER THE SECURITIES ACT OF 1933
}

\author{
R. W. Goldschmidt*
}

I

Since July 1933, no new issue of securities in excess of $\$ 100,000$ of a domestic corporation (other than a common carrier or a commercial bank) or of a foreign corporation or government with few exceptions to be mentioned presently, can lawfully be offered or sold in interstate commerce unless effectively registered under the Securities Act of 1933. Effective registration, which is controlled by the Securities Act and the rules and regulations of the Securities and Exchange Commission thereunder, includes the filing of a registration statement requiring detailed information about the issue to be registered and summary information about the issuer. On the basis of these registration statements, statistics of new issues effectively registered have been compiled from July 1933 to July 1934 by the Federal Trade Commission, and since August 1934 by the Research Division of the Securities and Exchange Commission. The statistics usually are released during the latter half of each month to cover registrations which have become effective during the preceding month.

The statistics of registrations contain so much more material on new issues than has been hitherto available to those compiling statistics of issues that they are bound to become the major source of information in this field. Their general use, however, has been hampered by two factors which to a large extent are inherent in their nature as by-products of administrative procedure. First, certain types of new issues, detailed in Section II are not included. Second, the statistics are based exclusively on the registration statements which are documents, giving registrants the right to offer and sell the securities covered thereby. The registration statements, of course, do not contain information about actual sales of registered securities, which can take place only after the statement has become effective. The figures tabulated by the Securities and Exchange Commission, therefore, represent compilations of registered intentions to sell securities rather than statistics of actual sales of securities. This problem will be discussed in Section III.

- Ph.D. 1927; Research Fellow, Brookings Institution, 1930-1931; Senior Finaxcial Beonomist, Securities and Exchange Commission. The author acknowledges indebtednew to Mr. Nathan Sameth, Miss Elaine S. Hosp and Mr. Ernest A. Grant, of the staff of the Research Division of the Securities and Exchange Commission, who prepared the statistical analysis of registered issues on which this article is based. 
Sections 3 and 4 of the Securities Act of 1933 define in detail which categories of securities and which types of offerings are exempt from registration. The chicf categories of new issues thus exempt are securities issued or guaranteed by the United States Government or by any political subdivision within the United States, securities issued by a religious, educational or charitable non-profit organization, securities issued by a common carrier or by a commercial bank, securities issued with the approval of the court in certain exchanges or reorganizations, securities sold only within the state where the issuer is incorporated, issues with an aggregate value of less than $\$ 100,000$ and issues not involving any public offering.

It would thus secm that securities registered under the Securities Act of 1933 represent only a rather limited part of the total new issues. However, sufficient information is available to the Commission with regard to most types of exempt issues to enable it to follow the trends in the field of exempt issues and to evaluate the influence of the different types of exempt issues on the capital market, and on the markets for registered securities. Important details relating to new issues by common carriers have to be reported to the Interstate Commerce Commission, while the Securities and Exchange Commission has organized the collection of information on securities under $\$ 100,000$ and on issues sold privately. Thus, of the categories of exempt corporate issues there are only two, viz., intrastate issues of domestic corporations and issues of bank stocks for which the Commission has to rely exclusively on the information available in newspapers and financial services.

Of all categories of exempt corporate issues, securities not offered publicly, but sold privately to a small number of buyers (so-called private placings) have been the most important during the three years since the Securities Act was enacted. The Research Division of the Commission has been sending a short questionnaire to every company which is reported in the financial press to have placed an issue privately. From the replies to such questionnaires, it appears that in the three years ending September 30, 1936, a total of almost $\$ 800,000,000$ of securities in about no individual issues has been placed privately. This compares with about $\$ 7,250,000,000$ of securities in about $1,45^{\circ}$ individual statements registered during the same period under the Securities Act of 1933 . Approximately $25 \%$ of all private placings have been registered by the issuers under the Securities Act of 1933 either before or-as more often happens-after sale, thereby reducing the amount of unregistered private placings of which the Commission has knowledge to somewhat above $\$ 565,000,000$ in about 90 issues, or $8 \%$ of all registered issues. Table I showing unregistered private placings when compared to securities registered under the Securities Act of r933 indicates that private placings attained their largest relative importance in the second half of 1934 and in the first half of 1935 when they were equivalent to $29 \%$ and $27 \%$, respectively, of securities registered. Approximately $50 \%$ of all private 
Registration Under the Securities Act of 1933

Table I. Pruvate Placings of Corporate Securities ${ }^{1}$ (Excluding Rails)

January, r934-September, 1936

(In Thousands of Dollars)

\begin{tabular}{|c|c|c|c|c|c|c|c|}
\hline \multirow[b]{2}{*}{ Year and Month } & \multicolumn{2}{|c|}{ TOTAL } & \multicolumn{2}{|c|}{ SECURITY TYPE } & \multicolumn{3}{|c|}{ CLASSIFICATION OF ISSUERS } \\
\hline & $\begin{array}{c}\text { Number of } \\
\text { Insues }\end{array}$ & Amount & $\begin{array}{l}\text { Bonds and } \\
\text { Notes }\end{array}$ & Stocks & $\begin{array}{l}\text { Public } \\
\text { Utility }\end{array}$ & Industrial & $\begin{array}{l}\text { Miscel- } \\
\text { laneous }\end{array}$ \\
\hline 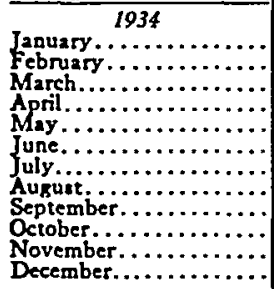 & $\begin{array}{l}2 \\
i \\
i \\
i \\
1 \\
1 \\
2 \\
1 \\
2 \\
6 \\
3\end{array}$ & $\begin{array}{r}\$ 12.000 \\
\because 2,000 \\
i, 147 \\
6,654 \\
6,500 \\
10,315 \\
10,000 \\
1,146 \\
48,903 \\
5,076\end{array}$ & $\begin{array}{r}\$ 12,000 \\
\ldots \ldots \\
\cdots \ldots \\
\because 1,247 \\
\because \ddot{6}, 500 \\
10,315 \\
10,000 \\
48,76 j \\
5,076\end{array}$ & 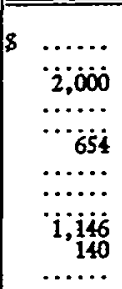 & $\begin{array}{r}\$ 12,000 \\
3,000 \\
i, 247 \\
654 \\
\because 6,315 \\
10,000 \\
19,32 j \\
2,086\end{array}$ & $\begin{array}{r}8 \ldots \ldots \\
\ldots \ldots . \\
\ldots \ldots . \\
\ldots \ldots \\
\because \cdots \\
6,500 \\
4,000 \\
1,146 \\
29,140 \\
2,990\end{array}$ & 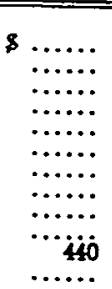 \\
\hline Totaz........... & 20 & $\$ 97,841$ & $\$ 93,901$ & $\$ 3,940$ & 853,625 & $\$ 43,776$ & 440 \\
\hline 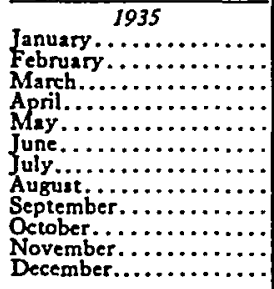 & $\begin{array}{l}7 \\
2 \\
1 \\
4 \\
3 \\
7 \\
4 \\
7 \\
4 \\
4 \\
4 \\
1\end{array}$ & $\begin{array}{r}\$ 45,805 \\
38,950 \\
450 \\
6,808 \\
33,190 \\
51,431 \\
13,403 \\
31,778 \\
16,, 180 \\
24,690 \\
30,800 \\
3,500\end{array}$ & $\begin{array}{r}45,805 \\
38,950 \\
450 \\
5,050 \\
33,190 \\
51,431 \\
13,403 \\
31,778 \\
16,, 180 \\
24,690 \\
30,800 \\
3,500\end{array}$ & 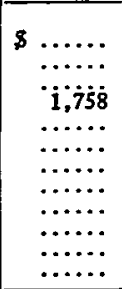 & $\begin{array}{r}453 \\
1,950 \\
450 \\
3,808 \\
33,190 \\
21,181 \\
10,403 \\
24,378 \\
1,, 550 \\
21,690 \\
14,800 \\
3,500\end{array}$ & $\begin{array}{r}\$ 22,602 \\
37,000 \\
3,000 \\
3,000 \\
28,000 \\
3,000 \\
7,400 \\
14,600 \\
3,000 \\
16,000 \\
\ldots \ldots\end{array}$ & 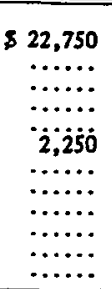 \\
\hline Total........... & 48 & $\$ 296,985$ & 8295,227 & \& 1,758 & $\$ 137,353$ & $\$ 134,632$ & $\$ 25,000$ \\
\hline 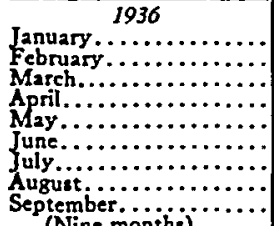 & $\begin{array}{l}3 \\
2 \\
4 \\
1 \\
1 \\
3 \\
3 \\
7 \\
1 \\
i\end{array}$ & $\begin{array}{r}86,050 \\
8,650 \\
24,286 \\
7,000 \\
13,500 \\
75,090 \\
75,500\end{array}$ & $\begin{array}{r}\$ 36,050 \\
8,650 \\
23,100 \\
7,000 \\
13,500 \\
75,090 \\
-5,500\end{array}$ & 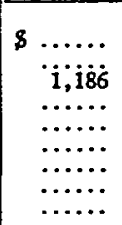 & $\begin{array}{l}\$ 3,000 \\
i \ddot{16,600} \\
\cdots \cdots \\
\ddot{3}, 000 \dot{0} \\
65,019 \\
\ddot{5, j 000}\end{array}$ & 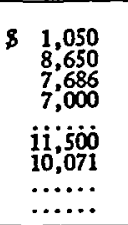 & 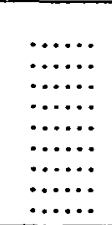 \\
\hline TotяL............. & 21 & $\$ 171,076$ & $\$ 169,890$ & 81,186 & $\$ 125,119$ & $\$ 45,957$ & $\cdots \cdots$ \\
\hline Grand Total. ... & 89 & 8565,901 & $\$ 559,018$ & 86,883 & 8316,097 & $\$ 224,364$ & $\$ 25,440$ \\
\hline
\end{tabular}

${ }^{x}$ Registered private placings excluded.

placings have been issued by electric utilities, oil companies ranking second with about $15 \%$. Practically all of the privately placed issues were high grade bonds but a few debentures and preferred stocks were interspersed. On the average, a private issue was sold to about five buyers. Life insurance companies constituted by far the most important class of buyers of private placings, taking approximately twothirds of the issues for which detailed figures are available to the Commission.

Under Commission Rule 202 issuers of securities in excess of $\$ 30,000$, but not aggregating over $\$ 100,000$, are required to file certain data with the Commission, although they need not furnish all of the material required for full registration. On the basis of these data, it appears that the total value of such securities offered for sale in interstate commerce has amounted to about $\$ 2,000,000$ to $\$ 3,000,000$ per month during the current year. It aggregated about $\$ 13,400,000$ during the year 1934, $\$ 25,500,000$ during the year 1935 and $\$ 23,600,000$ during the first nine months 
of 1936, or less than I per cent of fully registered issues. These figures refer to issuers' intentions and it is most likely that actual sales of issues of this type have amounted only to a fraction of the totals filed with the Commission. No information is available on issues below $\$ 30,000$, but the aggregate amount of such issues offered publicly is most probably negligible.

III

The totals of new securities effectively registered, which total more than $\$ 7,250$,$000,000^{2}$ from the date the Securities Act became effective to September 30, 1936, overstate the amount of actual sales of such securities for two reasons: (I) certain securities are registered which are not intended for immediate cash sale by the issuer, and (2) not all registered securities intended for immediate cash sale are actually sold.

Securities not intended for immediate cash sale are of considerable importance. During the two years from October I, 1934 to September 30, 1936 registered securities not intended for immediate cash sale for account of the issuers totaled approximately $\$ 1,040,000,000$ out of a grand total of effective registrations of new securities of about $\$ 6,350,000,000$, or approximately $16.4 \%$. The total of securities not intended for immediate cash sale is made up of three chief classes.

(I) Securities registered by the issuer for account of others. These registrations are for securities already outstanding, but not held by the issuer, which may or may not be intended for immediate cash sale by the owners. Registrations of this type totaled about $\$ 290,000,000$, or less than $5 \%$ of total registrations of new securities during the period from October 1, 1934 to September 30, 1936.

(2) Securities reserved for conversion, the exercise of options and for other subsciquent issuance. The securities reserved for conversion-about $\$ 350,000,000-$ represent duplications of other securities being registered at the same time which they will supersede on the exercise of the conversion privileges. During the period from October.I, 1934 to September 30, 1936, slightly above $\$ 500,000,000$ of securities, or almost $8 \%$ of total registrations, were for securities reserved for conversion, options or other subsequent issuance.

(3) Securities to be exchanged by issuers for other assets, amounting to over $\$ 250,000,000$, or $4 \%$ of all registrations of new securities during the two years ending September 30,1936 . More than nine-tenths of securities in this group consisted of securities to be exchanged for other securities either of the issuer or of others.

Details about the various types of securities registered but not intended for immediate cash sale by the issuer may be found in Table IV. It has not been possible

2 This figure excludes about $\$ 39,000$, 000 of securities in 47 statements which have been registered but which have been withdrawn (33 statements) or otherwise deprived of effectiveness ( 14 statements) after the date of their original effective registration up to September 30, 1936. Total filings for uew securities up to September 30, 1936 amounted to about $\$ 8,200,000,000$ in 1986 statements. These figures include in addition to issues effectively registered as at September 30, 1936, all issues (whether previously effective or not) withdrawn (269 statements for about $\$ 300,000,000$ ) or deprived of effectiveness and (117 statements for about $\$ 560,000,000)$ under examination at that date. 
to segregate the securities not intended for immediate cash sale from securities to be offered for cash in certain tabulations (for instance, those on the type and the industry of registered securities given in Tables II and III). However, securities not intended for immediate cash sale do not enter into the tabulations of estimated net proceeds given in Table $\mathrm{V}$ which, therefore, represent the amount of cash which registrants intended to raise through the sale of registered securities.

When a registered issue is fully and unconditionally underwritten, it can always be assumed that the issuer receives the full amount of the expected net proceeds and that the securities are sold for cash in their entirety to investors even if distribution may take some time and the underwriters may have to make concessions from the price originally contemplated. The only exception, the failure of the underwriting banking house to live up to its commitments, is so rare as to be negligible. For issues underwritten the registration statistics may be assumed to indicate correctly the actual amount of sales and the actual net proceeds to the issuer. It is, therefore, important to know that securities underwritten have constituted the great majority of total securities registered since the spring of 1935 . For the first nine months of 1936 , for instance, $76 \%$ of all registered sccurities were underwritten. The proportion of securities underwritten during the first half of 1936 came very near to $100 \%$ for utility companies, $90 \%$ for transportation and communication companies, and about $70 \%$ for industrial corporations. However, it fell to about $8 \%$ for financial companies and to only $2 \%$ for mining companies. Before the spring of 1935 , on the other hand, a large part of the total securities registered was not underwritten, but was intended to be distributed by the issuers directly or through agents.

In order to obtain at least a reasonable approximation to the actual volume of sales of registered securities noi inderwritten, the Research Division early in 1936 began to send out to registrants, other than seasoned companies, short questionnaires requesting information about actual sales of issues not sold to underwriters. The results of the replies received up to date which generally cover sales up to December 31, 1935 of securities registered before June 30, I935 are rather remarkable. Of all registered securities not underwritten other than issues of investment companies, considerably less than $20 \%$ was actually sold. For investment companies, which represent the majority of all registered securities not underwritten, the proportion is about $25 \%$, although the determination of the exact ratio between securities registered and securities sold is particularly difficult here because of the existence of authorized but unsold blocks of securities in July 1933 which could be sold through continuous offering without registration after the effective date of the Securities Act; if these blocks could be excluded, the proportion of sales to registrations would be considerably lower.

On the basis of the material collected through these follow-up questionnaires, it may be estimated very roughly that out of total registrations of new securities up to September $3^{0}, 193^{6}$ of about $\$ 7,250,000,000-$ a figure which excludes securities 
registered which were later withdrawn or deprived of effectiveness-certainly more than $\$ 1,000,000,000$ and possibly as much as $\$ 1,300,000,000$ were not sold in addition to about $\$ 1,150,000,000$ of registered securities not intended for immediate cash offering. This leaves cash sales of registered securities of less than $\$ 5,000,000,000$. Until registrants are requested to submit regularly a report on the progress of sales of registered securities the safest method for anybody analyzing the statistics of registration is probably to take only the amounts underwritten (which are given in Table $\mathrm{V}$ of the Commission's monthly release on registration statistics) and to add thereto a fraction of the registered securities to be sold directly by issuers or through agents.

\section{IV}

Securities issued in reorganizations and in exchange transactions, except as exempt under Section 3(a)(7) and 3(a)(10) of the Securities Act-i.e., broadly speaking securities issued with the approval of a court or a governmental agencyhave to be registered, and the Securities and Exchange Commission publishes monthly a few summary tables of such registrations. However, reorganization and exchange securities registered under the Securities Act constitute what is, from an economic point of view, only a more or less arbitrary selection of all issues of this type. This is, therefore, hardly an occasion for an analysis of these statistics which now constitute Tables VI and VII of the Commission's monthly release. Total registrations of such reorganization or exchange securities have amounted to about $\$ 480,000,000$ up to September 30, 1936, practically none of which represents new money raised by registrants.

\section{$\mathrm{V}$}

Within the limits discussed in detail in Sections II and III the statistics of effectively registered securities give a more detailed picture of the American new issue market than has been available hitherto. The chief results of these statistics have been summarized in Tables II-V. The first shows the total estimated gross proceeds of all effective registrations of new securities classified by the chief industries. 'The second presents a break-down of the same total by types of securities. Both Table II and Table III include securities not intended for immediate cash sale. Table IV details the sccurities not intended for immediate cash sale and thus reduces the total gross registrations of new securities to registered securities to be offered for cash sale; it further shows the estimated costs of distribution of the securities registered ending with the estimated net cash proceeds to be raised by the issuers through the sale of registered securities. The distribution of the estimated net proceeds according to purposes is then shown in Table V. Tables II and III cover the entire period since the Securities Act became effective, i.e., the months of July 1933 to September 1936; Tables IV and V start only with September 1934 when the Research Division of the Securities and Exchange Commission rearranged and extended the compilations of the Federal Trade Commission. The omission of the months from 
July 1933 to August 1934 from Tables IV and $V^{1}$, however, is not a very serious matter because out of about $\$ 7,250,000,000$ of securities registered up to September 30, 1936, less than $\$ 1,000,000,000$ were registered from July 27, I933 to August 3 , I934.

\section{VI}

A glance at any of the tables will show that there have been two sharply distinct periods in the registration of new securities under the Securities Act. During the first period which ran from July I933 to February 1935 the volume of registrations was relatively small and investment companies and mining companies predominated among the issuers. Registrations during this period amounted to about $\$$ I,I00,000,000 or not much over $\$ 50,000,000$ per month and about $\$ 1,750,000$ per statement. Moreover, it may be estimated that only the minority of the securities registered during that period has actually been sold,--probably not more than about $\$ 400,000$,000 , a monthly average of hardiy $\$ 20,000,000$. Registrations during the second period beginning with March I935 have totalled over $\$ 6,200,000,000$ up to September 30 , I936, a monthly average of over $\$ 320,000,000$ and an average of over $\$ 7,100,000$ per statement. The great majority of registrations during this period-exclusive, of course, of securities not registered for immediate cash sale-has actually been sold. Total cash sales during this period probably reach nearly $\$ 4,500,000,000$ or an average of about $\$ 240,000,000$ per month.

While investment companies and mining companies predominated during the first period, .electric utilities and manufacturing industries (particularly steel and oil) have accounted for the great majority of all registrations since the spring of 1935. The predominance of utilities and manufacturing industries would be considerably more pronounced than indicated in Table II if the compilation could be made on the basis of actual sales rather than on the basis of registrations. The reason for the rather sharp change in the distribution of total registrations among the chief industries, of course, is the revival of the bond market which definitely started early in 1935 and has continued up to date, and which has centered hitherto on refunding issues.

The same tendencies are reflected in the change of the type of securities registered as shown in Table III. Up to the spring of 1935 common stocks and certificates of participation (used instead of common stock in certain investment companies), for the most part not underwritten, contributed the great majority of all registered securities accounting for about $70 \%$ of the total for the first 20 months of registrations under the Securities Act. For about a year from the spring of 1935 fixed interest securities dominated the picture aggregating about $73 \%$ of all registrations from March 1935 to February 1936. It is only during the last few months that preferred stocks and common stocks (most of which were underwritten) have been registered in considerable amounts by seasoned issuers, indicating the reaching of another step in the full reopening of the capital market.

${ }^{2}$ Tables II-V will be found commencing on p. 28 , infra. 
From an economist's point of view possibly the most interesting information and that where the statistics of registration represent the greatest advance over the data previously available, is provided by the statistics of the distribution of net proceeds summarized in Table V. During the first period through February 1935, almost $6 \% \%$ of the total estimated net proceeds of registered new securities was intended for investment in securities, representing almost the totality of registrations by investment companies. About $15 \%$ of the total was intended to be used for repayment of indebtedness, $10 \%$ for working capital and only about $6 \%$ for the acquisition of plant and equipment. If it were possible to base the compilations on actual expenditures instead of registrants' estimates, which are known not to have been realized in a great number of cases, the absolute and relative amount of funds raised by the sale of registered new issues used in the acquisition of investment securities and to a lesser degree of those used to increase working capital or to acquire additional capital assets would undoubtedly be much smaller than that indicated in the statistics of registration with an equivalent increase of the proportion used for the repayment of indebtedness. During the second period beginning with March 1935 and ending with September 1936 the repayment of indebtedness completely dominated the picture. According to the registration statements approximately $76 \%$ of total net proceeds from the sale of securities registered during that period were intended to be used for the repayment before or at maturity of bonds, notes, and other indebtedness or for the retirement of preferred stock. Investment in securities with about $\mathrm{xI} \%$ of the total came next, followed by working capital with about $8 \%$, and plant and equipment with about $4 \%$. Here again the proportion of total net proceeds used for the repayment of indebtedness (including retirement of preferred stock) would be higher if the calculations could be based on actual expenditures; the ratio in that case probably would rise to about $90 \%$ of the total.

There has been much discussion of the amount of money raised by new issues of securities during this recovery for the purpose of enlarging the productive equipment of the country. The statistics of registrations give only a partial answer to this question. They indicate that in the 39 months to September 30, 1936, during which the Securities Act of 1933 was in effect, registrants intended to use about $\$ 250,000,000$ out of the expected total, net proceeds of registered new securities for the acquisition of plant, equipment and machinery, and that they further intended to use about $\$ 500,000,000$ to increase their working capital. Very little is known about the actual amounts expended by registrants on plant or equipment and working capital. However, it is likely that actual expenditures were considerably below intended expenditures. Even if intentions are discounted only to a small degree and if it is assumed that the majority of money raised for working capital finally finds its way into capital goods, the total amount of money actually raised by registered securities and used to provide additional capital goods can hardly have amounted to more than about $\$ 500,000,000$, i.e., not much over $\$ 10,000,000$ per month. This is obviously an item of very small importance in relation to the total amount of money spent 
each year in the United States on new durable goods. However, intended expenditures on plant and equipment and working capital have increased considerably in absolute amounts and in relation to total net proceeds of registered securities during recent months; they aggregated about $\$ 225,000,000$, or $33 \%$ of the total, during the third quarter of 1936 , compared with $\$ 230,000,000$, or $19 \%$, during the second quarter and $\$ 70,000,000$ or $8 \%$ during the first quarter of the year. Moreover, expenditures on plant and equipment are sometimes made out of current funds for which the registrant's treasury is reimbursed, or out of short term credits which are repaid out of the proceeds of a later issue. Such expenditures are included in the statistics under repayment of indebtedness if not clearly segregated in the registration statement with the result that expenditures on plant and equipment as shown in the statistics understate their actual amount.

\section{VII}

The change in the character of registered new issues which occurred in the spring of 1935 is finally reflected clearly in the development of the cost of distribution which is made up, on the one hand, of the underwriting or agency commissions and, on the other, of technical expenses coincident with an issue such as legal and accounting fees, stamp taxes, transfer agent's fees, etc. In the early months of the Securities Act, the average cost of distribution ran well over $10 \%$ of the estimated total gross proceeds of an issue. The actual ratio of costs of distribution to total receipts from sale of securities was still considerably higher than this, a reduction of the costs of issuance in step with the failure to sell the entire registered issue not being feasible in many cases. Average costs of distribution fell to about $4 \%$ when large refunding issues began to predominate and have continued around that level until early in 1936 when the increase of stock issues-which always entail a higher selling commission-forced this ratio slightly upward. The statistics show that approximately $80 \%$ of the total estimated expenses of issuance and distribution represent the cost of underwriters' or agents' commissions, leaving about $20 \%$ for all other expenses which include the costs of preparing the registration statement. In view of the numerous discussions of the additional cost of registration it may be of interest that various rather careful estimates made on the basis of registration statements filed with the Commission indicate that such additional costs are on the average below $1 / 2 \%$ of gross proceeds for issues above $\$ 1,000,000$ and probably do not amount to even $1 / 4 \%$ at the present time. They are, of course, relatively heavier for small issues, but the same relationship between costs of issuance and size of issue obtained before the Securities Act became effective. Moreover, it is very likely that the publicity provisions of the Securities Act and the general influence of the work of the Commission have reduced the costs of underwriting and other forms of distribution to a degree more than sufficient to offset completely any additional expenditures caused through registration. There is, therefore, no basis for the statement that the costs of registration have been a factor of importance in the relatively tardy reopening of the capital market, which has characterized the present recovery. 
Table II. New Securities Effectively Registered with the Securities and Exchange

Commission Classified by INDUSTRIES

(Estimated Gross Proceeds in Thousands of Dollars)

\begin{tabular}{|c|c|c|c|c|c|c|c|}
\hline Month and Year & $\begin{array}{l}\text { Extractive } \\
\text { Industries }\end{array}$ & $\begin{array}{l}\text { Manufac- } \\
\text { turing } \\
\text { Industries }\end{array}$ & $\begin{array}{l}\text { Financial } \\
\text { and } \\
\text { Investment }\end{array}$ & $\begin{array}{l}\text { Transport- } \\
\text { ation and } \\
\text { Communi- } \\
\text { cation }\end{array}$ & $\begin{array}{l}\text { Electric Light } \\
\text { and Power, } \\
\text { Gas and } \\
\text { Water }\end{array}$ & Other' & TOTAL \\
\hline 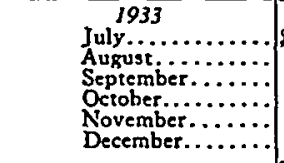 & $\begin{array}{l}925 \\
4,655 \\
1,652 \\
1,465 \\
5,594 \\
5,874\end{array}$ & $\begin{array}{rr}8 & 770 \\
1,674 \\
12,814 \\
17,130 \\
12,277 \\
22,991 \\
\end{array}$ & \begin{tabular}{|r}
8161,961 \\
34,628 \\
4,272 \\
12,945 \\
56,816 \\
31,152
\end{tabular} & 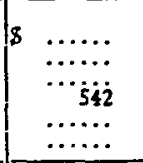 & 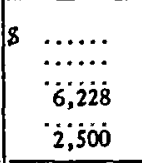 & 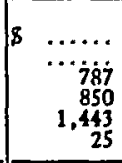 & $\begin{array}{rr}8163,656 \\
40,957 \\
19,525 \\
39,155 \\
76,130 \\
62,542 \\
\end{array}$ \\
\hline Montaly Avernar..... & 83,361 & 11,276 & $\$ 50,295$ & 90 & 1,455 & 517 & 866,994 \\
\hline 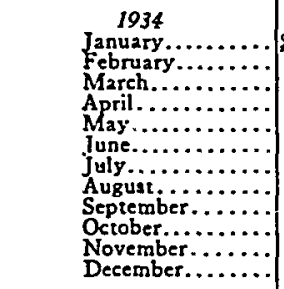 & $\begin{array}{r}969 \\
6,174 \\
3,606 \\
5,381 \\
6,117 \\
461 \\
600 \\
2,748 \\
1,282 \\
803 \\
150 \\
3,861\end{array}$ & $\begin{array}{r}11,057 \\
8,627 \\
6,160 \\
19,610 \\
5,051 \\
5,394 \\
5,390 \\
21,291 \\
1,379 \\
4,164 \\
1,424 \\
1,017\end{array}$ & $\begin{array}{r}54,187 \\
29,101 \\
12,413 \\
78,398 \\
5,910 \\
48,611 \\
51,445 \\
13,851 \\
30,783 \\
4,500 \\
12,982 \\
34,938\end{array}$ & 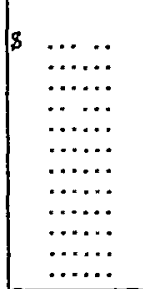 & $\begin{array}{r}30,000 \\
\because 8,667 \\
\ldots 187 \\
43,500 \\
2,374 \\
20,100 \\
9,600 \\
\ldots \ldots\end{array}$ & $\begin{array}{r}556 \\
2,038 \\
2,538 \\
3,013 \\
2,385 \\
330 \\
602 \\
3,346 \\
186 \\
10,391 \\
425\end{array}$ & $\begin{array}{r}66,769 \\
75,940 \\
24,717 \\
115,569 \\
19,463 \\
54,983 \\
101,537 \\
41,236 \\
36,004 \\
29,567 \\
34,547 \\
40,241\end{array}$ \\
\hline Monthly Avernae. & 2,679 & 7,547 & 31,468 & 8 & 9,536 & 2,151 & 853,381 \\
\hline 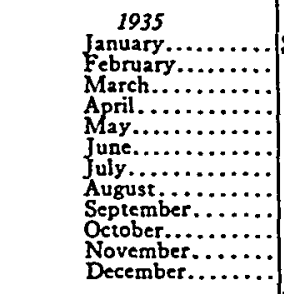 & $\begin{array}{r}1,750 \\
525 \\
6,603 \\
3,827 \\
8,892 \\
5,341 \\
1,518 \\
15,616 \\
5,060 \\
2,883 \\
5,322 \\
28,784\end{array}$ & $\begin{array}{r}8 \ldots 880 \\
45,136 \\
18,589 \\
89,033 \\
52,260 \\
210,669 \\
54,303 \\
150,532 \\
70,594 \\
68,604 \\
36,954\end{array}$ & \begin{tabular}{|r}
8 \\
7,310 \\
34,513 \\
24,257 \\
59,026 \\
18,802 \\
9,764 \\
95,695 \\
76,905 \\
9,888 \\
110,441 \\
14,384 \\
18,709
\end{tabular} & $\begin{array}{r}150 \\
\ldots \ldots \\
\ldots \ldots \\
i 0,039 \\
i 9,634 \\
\ldots \ldots \\
53,037 \\
16,830\end{array}$ & $\begin{array}{r}1,730 \\
8,875 \\
52,175 \\
73,755 \\
20,415 \\
123,382 \\
199,034 \\
32,182 \\
153,269 \\
163,011 \\
193,422 \\
35,553\end{array}$ & $\begin{array}{r}104 \\
50 \\
1,845 \\
400 \\
977 \\
1,884 \\
3,925 \\
75,056 \\
1,125 \\
7,121 \\
7,800 \\
45,250\end{array}$ & 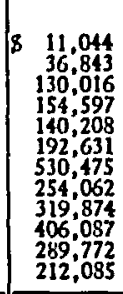 \\
\hline Montralx AVERnGE.... & 6,510 & 866,463 & 839,974 & 810,749 & 887,317 & $8 \quad 12,128$ & $\$ 223,141$ \\
\hline $\begin{array}{c}1936 \\
\text { January.... } \\
\text { February... } \\
\text { Mareh..... } \\
\text { April..... } \\
\text { May........ } \\
\text { June....... } \\
\text { July....... } \\
\text { Auguit.... } \\
\text { September. }\end{array}$ & $\begin{array}{r}6,578 \\
3,971 \\
425 \\
12,221 \\
10,327 \\
6,372 \\
3,701 \\
3,521 \\
2,958\end{array}$ & $\begin{array}{r}\$ 163,121 \\
60,703 \\
177 ;, 998 \\
263 ;, 893 \\
128,500 \\
232,075 \\
61,402 \\
55,473 \\
116,052\end{array}$ & $\begin{array}{rr}88,754 \\
36,190 \\
49,910 \\
71,822 \\
95,818 \\
69,348 \\
106,654 \\
114,140 \\
56,456\end{array}$ & $\begin{array}{r}2,720 \\
12,700 \\
155,176 \\
17,767 \\
22,002 \\
2,767 \\
3,861\end{array}$ & $\mid \begin{array}{r}27,810 \\
95,675 \\
237,182 \\
20,400 \\
79 ; 003 \\
197,350 \\
158,605 \\
49,516 \\
79,998\end{array}$ & $\begin{array}{rr}86,713 \\
15,850 \\
105,109 \\
43,501 \\
5,671 \\
16,827 \\
10,561 \\
60,605 \\
755\end{array}$ & $\begin{array}{r}8275,696 \\
212,089 \\
583,391 \\
751,013 \\
319,319 \\
523,439 \\
362,925 \\
286,022 \\
260,080\end{array}$ \\
\hline Moxrzer Averucz..... & 5,564 & 8139,913 & 869,899 & 822,384 & $\$ 125,504$ & 833,844 & $\$ 397,108$ \\
\hline
\end{tabular}

Includes securities of foreign governments and municipalities.

Table IV. Reduction of Estimated Gross Proceeds to Net Prockeds, By Months, of New Securities Registered for Account of Issuers and Fully Effective

SePteMBER I, I934-SePTEMBER 30, 1936

(In Thousands of Dollars)

\begin{tabular}{|c|c|c|c|c|c|c|c|c|c|}
\hline r. & $\begin{array}{l}\text { Sept. } \\
1934\end{array}$ & $\begin{array}{l}\text { Oct. } \\
1934\end{array}$ & $\begin{array}{l}\text { Nov. } \\
1934\end{array}$ & $\begin{array}{l}\text { Dec. } \\
1934\end{array}$ & $\begin{array}{l}\text { Jan. } \\
1935\end{array}$ & $\begin{array}{l}\text { Febr. } \\
1935\end{array}$ & $\begin{array}{c}\text { March } \\
1935\end{array}$ & $\begin{array}{l}\text { April } \\
1935\end{array}$ & May \\
\hline Grose proceeds of all effective securities $\ldots \ldots \ldots \ldots \ldots \ldots \ldots$ & 36,004 & 29.567 & 34,547 & 40,241 & 11,044 & 36,843 & 130,016 & 154,597 & 140,208 \\
\hline 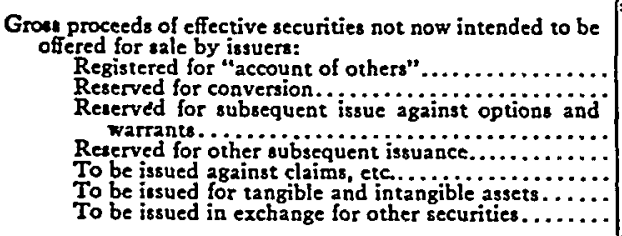 & $\begin{array}{r}1,712 \\
6,788 \\
5 \\
262 \\
2\end{array}$ & 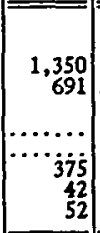 & 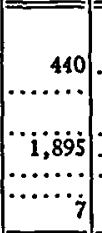 & 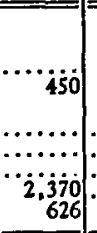 & a......... & 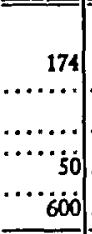 & $\left|\begin{array}{ccc}\cdots & \cdots & s \\
\cdots & \cdots & j \\
\cdots & \cdots & \cdots \\
\cdots & \cdots & \cdots\end{array}\right|$ & $\begin{array}{r}5,143 \\
19,146 \\
3 \\
\ldots \ldots \\
24,917\end{array}$ & $\left\{\begin{array}{r}10,231 \\
7,370 \\
1,294 \\
\ldots \ldots \\
\ldots \ldots \ldots \\
\ldots \ldots\end{array}\right.$ \\
\hline 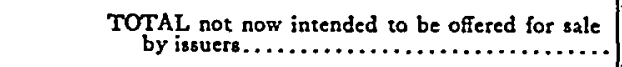 & 8,469 & 2,510 & 2,342 & 3,446 & 1,984 & 824 & 5,435 & 49.275 & 18,915 \\
\hline $\begin{array}{l}\text { Gross proceeds of securities now intended to be offered for } \\
\text { sale by issuers } . . . . . \ldots \ldots \ldots \ldots \ldots \ldots \ldots \ldots \ldots \ldots\end{array}$ & 27,535 & 27,057 & 32,205 & 36,795 & 9,060 & 36,019 & 124,581 & 105,322 & 121,293 \\
\hline $\begin{array}{l}\text { Selling and distributing expenses: } \\
\text { Commissions and discount to underwriters and agents } \\
\text { Other selling and distributing expenses................. }\end{array}$ & $\begin{array}{l}\text { (1) } \\
\text { (1) }\end{array}$ & 1,166 & $\begin{array}{r}1,486 \\
550\end{array}$ & $\begin{array}{r}2,495 \\
454\end{array}$ & 1,164 & $\begin{array}{r}2,708 \\
55 \\
\end{array}$ & 4.155 & 3.916 & 4.779 \\
\hline TOTAL selling and distributing expenses........ & 3,009 & 1,325 & 2,036 & 2,949 & 1,317 & 2,763 & 5,149 & 4,794 & 5,758 \\
\hline Estimated Net Proceeds.$\ldots \ldots \ldots \ldots \ldots \ldots \ldots \ldots$ & $\overline{24,526}$ & $\mid \overline{25,732}$ & $\overline{30,169}$ & 33,8461 & $\overline{7,743} \mid=$ & $\overline{33,256}$ & 119,432 & 100,528 & 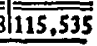 \\
\hline
\end{tabular}

(1) Breakup of figures for September 1934 not available. 
Table V. Proposed Uses of Net Proceeds, by Months, of New Securities Registered For Account of Issuers and Fully Effective September I, 1934-SEPTEMber 30, 1936

(In Thousands of Dollars)

\begin{tabular}{|c|c|c|c|c|c|c|c|c|c|}
\hline & $\begin{array}{l}\text { Sept: } \\
1934 \\
\end{array}$ & $\begin{array}{l}\text { Oct. } \\
1934\end{array}$ & $\begin{array}{l}\text { Novi } \\
1934\end{array}$ & $\begin{array}{l}\text { Dec: } \\
1934 \\
\end{array}$ & Jan. & $\begin{array}{l}\text { Febr. } \\
1935\end{array}$ & $\begin{array}{c}\text { March } \\
1935 \\
\end{array}$ & $\begin{array}{l}\text { April } \\
1935 \\
\end{array}$ & May \\
\hline Organization and development expenses.......... & $\ldots$ & $\ldots \ldots$ & 126 & 156 & 77 & $\overline{\ldots \ldots}$ & 366 & 802 & 108 \\
\hline 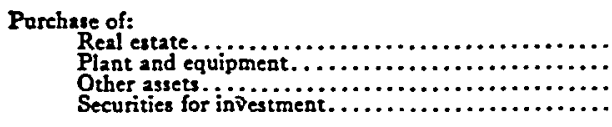 & $\begin{array}{r}1,02 i \\
204 \\
20,322\end{array}$ & $\begin{array}{r}320 \\
697 \\
4,070 \\
\end{array}$ & $\begin{array}{r}6,387 \\
11,060 \\
\end{array}$ & $\begin{array}{r}{ }_{1}, 15 j \\
557 \\
13,542 \\
\end{array}$ & $\begin{array}{r}5 \\
975 \\
5 \\
6,349 \\
\end{array}$ & 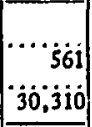 & $\begin{array}{r}1,643 \\
22,212 \\
\end{array}$ & $\begin{array}{r}203 \\
1,320 \\
46 \\
9,969 \\
\end{array}$ & $\begin{array}{r}47 \\
9,790 \\
14,182 \\
\end{array}$ \\
\hline TOTAI purchase of assets...... & 21,547 & 5,091 & 17,492 & 15,256 & 7,334 & 30,871 & 23,877 & 11,538 & 24,920 \\
\hline Increate of working capital.... & 2,058 & 284 & 4,310 & 761 & 274 & 1,776 & 1,033 & 8,091 & 10,954 \\
\hline Retirement of preferred stock..... & $\ldots \ldots \ldots$ & $\ldots \ldots$ & $\ldots \ldots$ & $\ldots \ldots \ldots$ & $\ldots \ldots$ & $\ldots \ldots \ldots$ & $\ldots$ & $\ldots \ldots$ & $\ldots \ldots$ \\
\hline Reimbursement of loans used for capital expenditur & $(1)$ & $(1)$ & (12 & (1) & $(1)$ & $(1)$ & (1) & (1) & $(1)$ \\
\hline 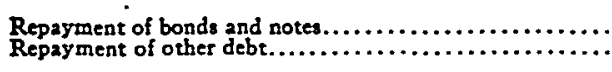 & 922 & $\begin{array}{r}19.688 \\
470 \\
\end{array}$ & $\begin{array}{r}7,835 \\
220 \\
\end{array}$ & $\because \overline{i 7,673}$ & & 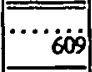 & $\begin{array}{r}85,955 \\
7,811 \\
\end{array}$ & $\begin{array}{r}74,898 \\
5,192 \\
\end{array}$ & 69,904 \\
\hline TOTAL repayment of indebtedness........ & 922 & 20,158 & 8,055 & 17,673 & 57 & 609 & 93,766 & 80,090 & 79,553 \\
\hline Mircellaneous and unaccounted for.............. & …...... & 199 & 186 & $\ldots \ldots$ & $\ldots \ldots$ & $\ldots \ldots$ & 390 & 7 & $\ldots \ldots$ \\
\hline TOTAL.............. & 24,527 & 25,732 & 30,169 & 33,846 & 7,742 & 33,256 & 119,432 & 100,528 & 115,535 \\
\hline
\end{tabular}

\begin{tabular}{|c|c|c|c|c|c|c|c|c|c|}
\hline \multirow[b]{2}{*}{ Organization and development expenses................ } & \multicolumn{9}{|c|}{ PERCENT OF TOTAL } \\
\hline & $\ldots \ldots$. & $\ldots \ldots$ & 0.4 & 0.5 & 1.0 & $\ldots . . . .$. & 0.3 & 0.8 & 0.1 \\
\hline 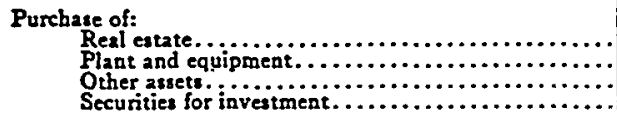 & $\begin{array}{r}4.2 \\
0.8 \\
82.9 \\
\end{array}$ & $\begin{array}{r}1.2 \\
2.7 \\
0.0 \\
15.8 \\
\end{array}$ & $\begin{array}{r}00 . \\
21.2 \\
36.7\end{array}$ & $\begin{array}{r}3.5 \\
i .6 \\
40.0 \\
\end{array}$ & $\begin{array}{r}0.1 \\
12.6 \\
82.1 \\
82.0 \\
\end{array}$ & 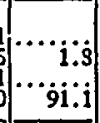 & $\begin{array}{r}0.0 \\
1.4 \\
0.0 \\
18.6 \\
\end{array}$ & $\begin{array}{l}0.2 \\
1.3 \\
0.1 \\
9.9\end{array}$ & $\begin{array}{r}0.0 \\
8.5 \\
0.5 \\
12.6 \\
\end{array}$ \\
\hline TOTAL purchase of agsets. . . . . . . . . . . . & 87.9 & 19.7 & 58.0 & 45.1 & 94.8 & 92.9 & 20.0 & 11.5 & 21.6 \\
\hline Inerease of working capital. ............. & 8.4 & 1.1 & 14.3 & 2.2 & 3.5 & $\overline{5.3}$ & 0.9 & $\overrightarrow{8.0}$ & 9.4 \\
\hline Retirement of prefersed stock ...................... & $\ldots \ldots$ & $\ldots \ldots$ & $\ldots \ldots$ & $\ldots \ldots$ & $\ldots \ldots$ & $\ldots \ldots$ & $\ldots \ldots$ & $\ldots \ldots$ & $\ldots \ldots$ \\
\hline Reimbursement of lozas used for capital expenditures..... & $(1)$ & (1) & (1) & (1) & (1) & (3) & (1) & (1) & (1) \\
\hline 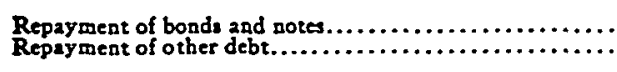 & $\cdots \cdots$ & $\begin{array}{r}76.5 \\
1.8 \\
\end{array}$ & $\begin{array}{r}26.0 \\
0.7 \\
\end{array}$ & $\because 32.2$ & $\cdots \cdots$ & $\cdots \cdots \cdot \dot{s}$ & $\begin{array}{r}72.0 \\
6.5\end{array}$ & $\begin{array}{r}74.5 \\
5.2 \\
\end{array}$ & $\begin{array}{r}60.5 \\
8.4 \\
\end{array}$ \\
\hline TOTAL repayment of indebtedness............ & 3.7 & 78.3 & 26.7 & 52.2 & 0.7 & 1.8 & 78.5 & 79.7 & 68.9 \\
\hline Miscellaneous and unaccounted for...... & $\ldots \ldots$ & 0.9 & 0.6 & $\ldots \ldots$ & $\ldots \ldots$ & $\ldots \ldots$ & 0.3 & 0.0 & $\ldots \ldots$ \\
\hline TOTAL.................. & 100.0 & 100.0 & 100.0 & 100.0 & 100.0 & 100.0 & 100.0 & 100.0 & 100.0 \\
\hline
\end{tabular}

(1) Amounts proposed for reimbursement of loans for capital expenditures, if any, are included in totals to be applied toward repayment of Tables II-V will be found commencing p. 28, 30, infra. 
Table V. Proposed Uses of Net Proceeds, by Months, of New Securittes Registered for Account of Issuers and Fully Effective September I, I934-September 30, I936

(In Thousands of Dollars)

\begin{tabular}{|c|c|c|c|c|c|c|c|c|c|c|c|c|c|c|c|}
\hline June & July & $\begin{array}{l}\text { Aug } \\
1935\end{array}$ & $\begin{array}{l}\text { Sept. } \\
1935\end{array}$ & (ct. & $\begin{array}{l}\text { Nov. } \\
1935\end{array}$ & $\begin{array}{l}\text { Dec. } \\
1935\end{array}$ & $\begin{array}{l}\text { Jan. } \\
1936\end{array}$ & $\begin{array}{l}\text { Febs. } \\
1936\end{array}$ & $\begin{array}{c}\text { March } \\
1936\end{array}$ & $\begin{array}{l}\text { April } \\
1936\end{array}$ & $\begin{array}{l}\text { May } \\
1936\end{array}$ & $\begin{array}{l}\text { June } \\
1936\end{array}$ & $\begin{array}{l}\text { July } \\
1936\end{array}$ & $\begin{array}{l}\text { Augs: } \\
1936\end{array}$ & $\begin{array}{l}\text { Sept } \\
1936\end{array}$ \\
\hline 257 & $\overline{111}$ & 462 & 670 & 730 & 1,231 & 663 & 1,033 & 750 & 116 & 210 & 1,360 & 2,002 & 409 & 401 & 209 \\
\hline $\begin{array}{r}6,900 \\
4,927\end{array}$ & $\begin{array}{r}1,790 \\
40,157\end{array}$ & $\begin{array}{r}40 \\
5,309 \\
75,491 \\
\end{array}$ & $\begin{array}{r}213 \\
5,514 \\
77,455\end{array}$ & $\begin{array}{r}331 \\
4,145 \\
85,495\end{array}$ & $\begin{array}{r}357 \\
6,324 \\
60 \\
9,034\end{array}$ & $\begin{array}{r}11 \\
2,357 \\
10,397\end{array}$ & $\begin{array}{r}250 \\
9,959 \\
1,133 \\
25,060\end{array}$ & \begin{tabular}{|r|r}
0,367 \\
3 \\
30,476
\end{tabular} & $\begin{array}{r}13 \\
9,486 \\
10,719 \\
41,04\end{array}$ & $\begin{array}{l}36,09 \\
597 \\
60,438\end{array}$ & $\begin{array}{r}25 \\
2,295 \\
46,907\end{array}$ & $\begin{array}{r}525 \\
31,817 \\
1,112 \\
716\end{array}$ & $\begin{array}{r}6,68 \\
750 \\
46,659\end{array}$ & $\begin{array}{r}20 \\
7,709 \\
4,666 \\
7,620\end{array}$ & $\begin{array}{r}598 \\
29,276 \\
435 \\
25,853\end{array}$ \\
\hline 11,633 & 42,037 & 30,910 & 13,182 & 90,920 & 15,775 & 13,599 & 36,402 & 36,013 & 61,260 & 97,129 & 49,923 & 34,200 & 54,093 & 20,015 & 56,162 \\
\hline$\overline{7,154}$ & $\overline{37,199}$ & 2,422 & $\overline{9,767}$ & 3,974 & 13,005 & $\overline{9,992}$ & 13,194 & $9,6,642$ & 20,712 & 26,836 & $\overline{27,466}$ & 33,099 & $\overline{36,721}$ & 109,257 & 31,751 \\
\hline$\because$ & 4,290 & $\overrightarrow{5,680}$ & 27,195 & 15,526 & 3,298 & 4,357 & 3,882 & 11,442 & 3,881 & 22,611 & 90,818 & 20,389 & 1,456 & 14,225 & 10,715 \\
\hline (2) & (1) & (1) & (1) & (1) & 13,838 & 23 & & & $\overline{\overline{5,531}}$ & 389 & $\cdots$ & 4,547 & & 2,926 & 250 \\
\hline $\begin{array}{r}136,821 \\
3,199\end{array}$ & $\begin{array}{r}371,225 \\
3,301\end{array}$ & $\begin{array}{r}170,296 \\
9,517\end{array}$ & $\begin{array}{r}174,603 \\
10,868\end{array}$ & $\begin{array}{r}182,380 \\
60,493\end{array}$ & $\begin{array}{r}186,875 \\
6,772 \\
\end{array}$ & 35,134 & $\begin{array}{r}186,067 \\
6,347\end{array}$ & $\begin{array}{r}107,289 \\
2,464\end{array}$ & $\begin{array}{r}358,392 \\
8,660\end{array}$ & $\begin{array}{r}438,685 \\
4,051 \\
\end{array}$ & $\begin{array}{r}80,079 \\
1,644\end{array}$ & $\begin{array}{r}274,234 \\
3,422\end{array}$ & $\begin{array}{r}192,840 \\
14,114\end{array}$ & $\begin{array}{r}51,402 \\
2,001\end{array}$ & 87,391 \\
\hline 140,020 & 374,526 & 179,813 & 185,471 & 242,873 & 193,647 & 157,778 & 192,414 & 109,753 & 367,052 & 442,736 & 81,723 & 277,656 & 206,954 & 53,403 & 88,236 \\
\hline$\ldots$ & $\overline{261}$ & 195 & & 3 & & & $\ldots \ldots \ldots$ & 285 & & 264 & $\ldots . . .$. & $\ldots \ldots$ & $\overline{161}$ & 736 & \\
\hline$\overline{159,064}$ & 458,424 & 219,482 & 236,285 & 354,026 & $\overline{240,794}$ & $\overline{186,412}$ & $\overrightarrow{246,925}$ & 167,885 & 458,552 & 590,175 & 251,290 & 371,893 & 299,794 & 200,963 & 187,323 \\
\hline
\end{tabular}

PERCENT OF TOTAL

\begin{tabular}{|c|c|c|c|c|c|c|c|c|c|c|c|c|c|c|c|}
\hline 0.2 & 0.0 & 0.2 & 0.3 & 0.2 & 0.5 & 0.4 & 0.4 & 0.4 & 0.0 & 0.0 & 0.5 & 0.6 & 0.1 & 0.2 & 0.1 \\
\hline $\begin{array}{l}3.1 \\
0.1 \\
3.1\end{array}$ & $\begin{array}{l}0.4 \\
0.0 \\
8.8\end{array}$ & $\begin{array}{r}0.0 \\
2.4 \\
0.0 \\
11.7\end{array}$ & $\begin{array}{c}0.1 \\
2.3 \\
3.2\end{array}$ & $\begin{array}{r}0.1 \\
1.2 \\
0.3 \\
24.1\end{array}$ & $\begin{array}{l}0.2 \\
2.6 \\
0.0 \\
3.6\end{array}$ & $\begin{array}{l}0.0 \\
1.3 \\
0.4 \\
5.6\end{array}$ & $\begin{array}{r}0.1 \\
4.0 \\
0.5 \\
10.1\end{array}$ & $\begin{array}{r}0.0 \\
3.2 \\
0.1 \\
18.2\end{array}$ & $\begin{array}{l}0.0 \\
2.1 \\
2.3 \\
9.0\end{array}$ & $\begin{array}{r}6.1 \\
0.2 \\
10.2\end{array}$ & $\begin{array}{r}0.0 \\
0.9 \\
0.2 \\
18.7\end{array}$ & $\begin{array}{l}0.1 \\
8.6 \\
0.3 \\
0.2\end{array}$ & $\begin{array}{r}2.2 \\
0.2 \\
15.6\end{array}$ & $\begin{array}{l}0.0 \\
3.8 \\
2.3 \\
3.8\end{array}$ & $\begin{array}{r}0.3 \\
15.7 \\
0.2 \\
13.8\end{array}$ \\
\hline 7.3 & 9.2 & 14.1 & 5.6 & 25.7 & 6.6 & 7.3 & 14.7 & 21.5 & 13.4 & 16.5 & 19.8 & 9.2 & 18.0 & 9.9 & 30.0 \\
\hline 4.5 & 8.1 & 1.1 & 4.1 & 1.1 & 5.4 & 5.4 & 5.4 & 5.7 & 4.5 & 4.5 & 10.9 & 8.9 & 12.3 & 54.3 & 17.0 \\
\hline ....... & 0.9 & 2.6 & 11.5 & 4.4 & 1.4 & 2.3 & 1.6 & 6.8 & 0.8 & 3.8 & 36.2 & 5.5 & 0.5 & 7.1 & 5.7 \\
\hline (2) & (1) & (1) & (1) & (1) & 5.7 & 0.0 & ….... & ..... & 1.2 & 0.1 & $\ldots$ & 1.2 & $\ldots$ & 1.5 & 0.1 \\
\hline $\begin{array}{r}86.0 \\
2.0\end{array}$ & $\begin{array}{r}81.0 \\
0.7\end{array}$ & $\begin{array}{r}77.6 \\
4.3\end{array}$ & $\begin{array}{r}73.9 \\
4.6\end{array}$ & $\begin{array}{l}51.5 \\
17.1\end{array}$ & $\begin{array}{r}77.6 \\
2.8\end{array}$ & $\begin{array}{l}65.8 \\
18.8\end{array}$ & $\begin{array}{r}75.3 \\
2.6\end{array}$ & $\begin{array}{r}63.9 \\
1.5\end{array}$ & $\begin{array}{r}78.2 \\
1.9\end{array}$ & $\begin{array}{r}74.3 \\
0.7\end{array}$ & $\begin{array}{r}31.9 \\
0.7\end{array}$ & $\begin{array}{r}73.7 \\
1.0\end{array}$ & $\begin{array}{r}64.3 \\
4.7\end{array}$ & $\begin{array}{r}25.6 \\
1.0\end{array}$ & $\begin{array}{r}46.7 \\
0.4\end{array}$ \\
\hline 88.0 & 81.7 & 81.9 & 78.5 & 68.6 & 80.4 & 84.6 & 77.9 & 65.4 & 80.1 & 75.0 & 32.6 & 74.7 & 69.0 & 26.6 & 47.1 \\
\hline & 0.1 & 0.1 & $\ldots . .$. & 0.0 & ...... & $\ldots \ldots$ & $\cdots \ldots$ & 0.2 & ..... & 0.1 & & ....... & 0.1 & 0.4 & ........ \\
\hline 100.0 & 100.0 & 100.0 & 100.0 & 100.0 & 100.0 & 100.0 & 100.0 & 100.0 & 100.0 & 100.0 & 100.0 & 100.0 & 100.0 & 100.0 & 100.0 \\
\hline
\end{tabular}

